\title{
Walras in the light of Marx, Lacan and his own
}

\author{
Walras sob as luzes de Marx, Lacan e dele mesmo
}

ELEUTÉRIO F. S. PRADO*

RESUMO: Neste artigo discute-se a concepção de ciência pura de Léon Walras, a qual naturaliza os preços de mercado. Mostra-se, depois, como Marx explica criticamente a naturalização dos fenômenos econômicos em geral. Em sequência - com base na teoria do sujeito de Jacques Lacan - indica-se de que modo o discurso da ciência positiva contribui para a formação do saber tecnocientífico e para a difusão da teoria neoclássica. Mostra-se, ademais, que essa compreensão do conhecimento contribui para desresponsabilizar os tecnocratas das consequências eventualmente funestas da aplicação da ciência positiva na sociedade.

PALAVRAS-CHAVE: Teoria do equilíbrio geral; Leon Walras; crítica da economia política; metodologia da economia.

ABSTRACT: This article discusses Léon Walras's conception of pure science, which naturalizes market prices. We then show how Marx critically explains the naturalization of economic phenomena in general. Then - based on Jacques Lacan's theory of the subject - we indicate how the discourse of positive science contributes to the formation of technoscientific knowledge and, specially, to the diffusion of the neoclassical theory. Moreover, the article shows that this understanding of knowledge contributes to deduct from the responsibilities of technobureaucrats for potentially disastrous consequences of the application of positive science to society.

KEYWORDS: General equilibrium theory; Leon Walras; criticism of political economy; economics methodology.

JEL Classification: B13; B41; B59.

\section{INTRODUCTION}

Karl Marx wrote in a footnote to the first chapter of Das Kapital that "Economists have a singular method of procedure. There are only two kinds of institu-

\footnotetext{
* Tenured and Senior professor of the Economics Department of Faculdade de Economia e Administração da Universidade de São Paulo - FEA/USP, São Paulo/SP, Brasil. E-mail: eleuter@usp.br. ORCID: orcid. org/0000-0003-3339-6809. Submitted: 6/January/2020; Approved: 2/February/2020.
} 
tions for them, artificial and natural. The institutions of feudalism are artificial institutions, those of the bourgeoisie are natural institutions" (Marx, 1867, p. 58n). However, even if he provided a good answer to the conundrum of why this duality applies to economists, he never explored all its consequences. After all, he was never witness to the mathematicization of political economy that only spread in the final quarter of the 19 th century.

It is imperative to point out that this distinction takes place not on the reality, but in language. Therefore, the notions of natural and artificial are both representations formed by signifier-signified pairs. As linguistics terms, they are both artificial, even if they cannot be regarded as conventions, but as signs that emerged over the centuries unintentionally and as part of the language formation process itself. As signifieds, they point - and by pointing, indicate gaps and uncertainties to what is peculiar to nature and what is peculiar to humankind. Institutions are always in the latter group - and not the former. Humankind creates institutions, whether consciously or, even more frequently, unconsciously.

Classic political economy regards prices as explicitly natural; in fact, it only designated as natural long-time trending prices, which stand apart from market prices, which depended on contingent conditions associated with how people interacted on the markets. After its gradual demise in the latter half of the 19th century, neoclassic theory emerges, and regards all prices as natural, even if this is no longer explicitly stated. The two traditions further converge by taking the institutions that enable the markers, and therefore prices, to exist - for example, explicit or implied, and formal or informal contracts - as natural, regarding interventions in their functioning as artificial. Therefore, different emphases and even substantive distinctions exist between a Jean B. Say and an Adam Smith; between a Stanley Jevons and an Alfred Marshall.

The remainder of the paper first introduces the science of Léon Walras and shows how Marx explains the naturalization of prices and economic phenomena in general. The next section shows - based on Jacques Lacan's Subject Theory how the discourse of science contributes to both the formation of technoscientific knowledge and to deduct from the responsibility of technobureaucrats for the eventually harmful consequences of the application of positive science to the conduction of society.

\section{WALRAS'S LAW}

Léon Walras stands as the founding father of neoclassic economics as it is currently known. He understood that Political Economy is both a display of what is and a program of what should be. In the former case, it stands as a science, and in the latter as an art and morality; as moral knowledge, it concerns the ends of the viewpoint of equity and justice, and as art (applied or technical science), it concerns the means to achieve the ends that interests determine. This field of knowledge 
therefore divides into three parts, and is thus composed and raised, according to Walras, from a strictly determined scientific knowledge.

Walras clearly states the metaphysical nature of economics as it stands beginning with his work. By metaphysical, he means an attempt to apprehend an order that is objectively given once-and-for-all - one that is therefore changeless, nonhistoric. This is precisely how he introduces the "pure political economy" that his compendium develops, pointing out that he designates entities as corporeal entities ("bodies") and the beings that lie implied in these entities' behavior as universals ("facts"):

A truth long ago made clear by the Platonic philosophy is that science does not study corporeal entities but universals of which those entities are the manifestations. Corporeal entities come and go; but universals remain forever. Universals, their relations, and their laws, are the subject of all scientific study (Walras, 1954, p. 61).

To discover the facts that pure economics pursues, Walras divides them into two categories: natural phenomena; and human phenomena. The former result from the play of the blind and ineluctable forces of nature and those which result from the exercise of the human will, a force that is "free and cognitive". Science proper, or natural science, concerns itself with natural phenomena. Human phenomena, by their turn, are the subject of pure moral science. The latter "advises, prescribes, directs", whereas the former "observes, exposes, explains". Consequently, natural science has not alternative to studying the relations between the causes and effects governing the phenomena, as the forces of nature are, to use a catchphrase, perfectly deterministic. There is a consequence to this distinction that it is worth underscoring:

The fact that man's will is cognitive and free makes it possible to divide every entity in the universe into two great classes: persons and things. Whatsoever is not conscious of itself and is not master of itself is a thing. Whatsoever is conscious of itself and master of itself is a person. Man, being both self-conscious and self-directing, is a person. Only man is a person; minerals, plants and animals are things... (Walras, 1954, p. 62)

Given this view, one must now ask how Walras faces the exchange of commodities, which he regards as a simple exchange of goods, of use values. He thus regards the things exchanged as mere utilities, even if he refers to them as commodities. These exchanges are known to involve persons and things; therefore, because the purpose of things, according to him, must be rationally subordinated to the purpose of persons, then exchanges are expected to be regarded as human phenomena. This, however, is not what he concludes. Instead, Walras explicitly writes: "thus any exchange value, once established, partakes of the character of a natural phenomenon, natural in its origins, natural in its manifestations and natural in essence." Exchange value, he argues, does not arise from an agreement be- 
tween the parties to an exchange, but merely and simply from the relative scarcity of the things exchanged. If things have value - he says - it is because they are rare, that is, a thing's value emerges from the double condition of being more or less useful while more or less limited in terms of quantity or availability.

Thus, obviously, the purpose of persons is subordinated to the purpose of things, which clearly files in the face of his moral postulate according to which it is the right of persons to determine the fate of things. Here lies an enigma that Walras never clarified, but that Marx duly solved.

Marx explained why economists naturalize prices, pointing out, furthermore, the reversal of positions between subject and object that the naturalization of social exchange relations implies. They apprehend as such - without critically understanding it, or even attempting to - the objectification of social relations that lies at the heart of the capitalist production mode. In the excerpt below, Marx expresses what Walras calls "rareté" - while opposing the latter author's proposed explanation of course - as the labor time socially necessary to produce industrially reproducible commodities. For Walras, rareté is subjective, peculiar to the economic agent's mind, even if exchange value is quite objective. For Marx, the abstract labor that constitutes a commodity's value and is expressed as exchange value is not recognized as such by these agents because it dwells in the social unconscious.

Values "vary continually, independently of the will, foresight and action of the producers. To them, their own social action takes the form of the action of objects, which rule the producers instead of being ruled by them. [...] the labor time socially necessary for their production forcibly asserts itself like an over-riding law of Nature. The law of gravity thus asserts itself when a house falls about our ears. The determination of the magnitude of value by labor time is therefore a secret, hidden under the apparent fluctuations in the relative values of commodities" (Marx, 1867, p. 49).

Walras once again states the Platonic metaphysical nature of his theory of prices and markets when he prescribes the method of pure political economy: "Wheat is worth 24 francs a hectoliter" - is the correct starting point. This fact, according to him, depends neither on the buyer's will nor on the sellers, nor even on agreement between the two. "This assertion is new and will seem strange; but I have just proved it to be true, and I shall elaborate the proof in what follows", that is, in the work yet to be presented. Pure political economy does not embrace the experimental method, but that which he terms rational. "Pure theory of economics is a science which resembles the physics-mathematical sciences in every respect" (Walras, 1954, p. 71):

The physics-mathematical sciences, like the mathematical sciences, in the narrow sense, do go beyond experience as soon as they have drawn their type concepts from it. From real-type concepts, these sciences abstract 
ideal-type concepts which they define, and then on the basis of these definitions they construct a priori the whole framework of their theorems and proofs. After that they go back to experience not to confirm but to apply their conclusions (Walras, 1954, p. 71).

If, however, contemporary neoclassic economists claim to test the theory-derived propositions that they profess to know and employ, if they claim to rely on Karl Popper's falsifiability method, they are either mistaken or even - unknowingly - lying because neoclassic Economics is non-falsifiable by nature. To remain with the Platonic metaphysical view to which it belongs, it is ever incapable of controlling the so-called coeteris paribus conditions. Furthermore, and now venturing beyond this view, one must bear in mind that neoclassic Economics dismisses the historic time in which everything takes place for a purely logical "time" that cannot be observed as such. Because neoclassic theory employs a criterion of truthas-correspondence borrowed from Platonic metaphysics, ${ }^{1}$ its possible truth can only be stated dogmatically, as Walras himself does.

We must now quote Walras's Law in its strict sense, beyond that characterized by its overall metaphysical construction, and which concerns markets' ideal functioning. The law reads as follows: "for the market to be in equilibrium [...] it is necessary and sufficient that the effective demand be equal the effective offer of each commodity" (Walras, 1954, p. 196). This sets the prices that he refers to as stationary. If there are " $n$ " commodities and if the price becomes stationary for $n$ -1 of them, the price of the $\mathrm{n}^{\text {th }}$ commodity will also become set at the stationary level. Furthermore, if there is excess demand for a certain commodity, it must rise in price; if, on the other hand, there is a surplus supply of the same commodity, it must fall in price. This mechanism became notoriously known as "Walrasian $t a$ tonnement".

For him, the state of equilibrium is ideal, even if almost real: "it never happens in the real world [...] that the effective demand and supply of services or products are absolute y equal. Yet equilibrium is the normal state, in the sense that it is the state towards which things spontaneously tend under a régime of free competition" (Walras, 1954, p. 224). The term "tend" enunciates, it is worth pointing out - a trend that must manifest itself virtually, as general equilibrium theory does not allow for exchanges outside of and away from equilibrium. To solve this, Walras imagines that the market is run by an auctioneer that cries false prices that undergo corrections until the actual prices emerge and exchanges can take place. Under this arrangement, the advent of equilibrium precedes exchanges. The fact that exchanges in real markets precede an equilibrium that is only possible in prin-

\footnotetext{
${ }^{1}$ Adorno and Horkheimer severely criticized this metaphysics: we cling to "a theory which attributes a temporal core to truth instead of contrasting truth as something invariable to the movement of history" (2002, p. xi). So did Nietzsche and Heidegger: "It was they who fundamentally critiqued the notion of truth as objectivity and who, appearances and their own intentions to the contrary, laid the basis for a radical new vision of democracy itself" (Vattimo, 2009, p. 3).
} 
ciple does not appear to have bothered Walras, an author who prizes the formal logic of arguments above all.

Note, however, that the stationary - and normal - prices thus defined differ from the natural prices of classic political economy: "The natural price, therefore, is, as it were, the central price, to which the prices of all commodities are continually gravitating" (Smith, 1804, p. 52). For Smith and Ricardo, natural prices are implied and exist in real lapse of time, precisely that within which the average labor productivities required to produce the commodities may be regarded as approximately constant. The prices that Walras defines are topical, explicit, equilibrium, even if approximate. In the former case, market prices effectively hover near natural ones, as these are determined by the production terms of the commodities. For neoclassic economics, on the other hand, every price is a market prices, so that this school must consider a virtual stabilization dynamic where stationary prices operate as attractors.

This more recent construction is a construction of instrumental reason that dreams of equilibrium in a complex and turbulent world where disequilibrium rules. It aims to stand as an appropriate, clear and certain apprehension of market price behaviors, a construction that stems from the need and pretentiousness to intellectually and effectively dominate things and phenomena in this sphere of society. Even if it is sometimes associated with economic freedom, the individual freedom to act according to one's interests in fact assumes the submission of all to a decentralized - "market" economic system. Indeed, as history has shown, it contemplates the possible advent of complete organization of economic life by means of a centralized system.

The positiveness of equilibrium, which is nowhere to be found in classic political economy, is yet another sign of the metaphysical zeal that has pervaded neoclassic economics from the outset and even before, as seen in the branch that originated with Jean B. Say. Although Walras distinguished a moral sphere of economic knowledge, he worked to find an exact, perfect, unshakeable scientific knowledge capable of driving a successful economic intervention technique.

Metaphysics has notoriously been, since its birth in ancient Greece, the firstborn child of fear, uncertainty, contradiction, tragedy and the haphazard unfolding of history. Its resurgence as par excellence scientific conception in the development of capitalism cannot, therefore, be seen as mere happenstance, as order in this system only emerges through disorder, as well as by means of irregular and periodic crises. It therefore stands as both the apologetics of the system's proper functioning and the tool of an economic policy that believes it can act to fix the system when it deviates from the idealized optimum.

Now, Marx never treated political economy as a natural science capable of making economic policy prescriptions. He never built models to mechanically represent the economic system's performance. For example, the notion of using general equilibrium theory as the basis for Socialist planning would have seemed quite absurd to him. Unlike his scientism-inclined followers, he never laid political practice on a supposedly sound scientism capable of driving, orienting and restraining human designs, as later illustrated by the historic slip caused by the unfortunate idea of scientific Socialism: the philosopher-party of the proletariat. Critique of 
utopian romanticism should never have fallen into ab objectivist logic that believed itself capable of prescribing ex-ante what was to come ex-post in history because it allegedly knew the rules that govern the evolution of history.

On the other hand, albeit without the same consequences, the political practice of neoclassic economists clearly shows a constant effort to block off policies that, under the banner of theorization, appear to threaten the "good" functioning of the economic system such as it is. Only a weak scientism based on interpretations open to criticism, to debate, to collective decision-making, can be consistent with a democracy that is more than just formal and apparent - but that is still better than any dictatorship. Neoclassic economists, like the Soviet Union's bureaucrats, cannot deny that they occasionally promote policies that cause silent suffering and even casualties by the thousands. Should they, however, take the blame for these so-called "collateral" events? What do they claim when they deny this as a possibility?

\section{IDEOLOGY AND/OR TECHNOSCIENCE}

For Marx, Walras's mistake as discussed above is a consequence of an ideology that rises spontaneously from the sphere of the capitalist production mode's mercantile circulation; by ideology, he always meant a socially necessary appearance. Commodities exchanges do stand as natural facts under Capitalism, even if they are implicitly social events. To engage the exchange of commodities in a truthful way according to this self-professed critical view, one must stand side by side with Marx and say that this creates "social relations of things", or relations of commodity fetishism.

On the other hand, the same appearance requires a hard and vulgar scientism like the neoclassical theory, which is content to apprehend the apparent linkages between phenomena as "types" or "facts". Many economists believe that Marx also formulated a metaphysical concept of Capitalism because he used the abstract labor category to explain the values that emerge from values in exchange. They miss the fact that, for Marx, Capitalism is itself metaphysical: did he not write that commodities are sensible-supersensible things?

To better understand this, one must resort to critical knowledge as developed by Jacques Lacan as a science of language wherein dwell social subjects after the tradition of Sigmund Freud. ${ }^{2}$ The first key lesson learned from this clash of cultures is that humans are language beings and that this form of existence has a value at a part with genetic heritage: the very physical existence of human beings becomes impossible without mastery of a language, the almost endless worth of the words that form it.

Language is a system of signifiers that an individual must enter to take their

\footnotetext{
${ }^{2}$ A large portion of what comes next is based on a book by Jean-Pierre Lebrun (2008) where Jacques Lacan's main teachings are presented in a manner accessible to those who are not active in the field of psychoanalysis and have not studied the author for years on end.
} 
place among their peers. Earning the ability to speak implies distancing one's self from reality, not being in direct contact with things, living forever in this environment, this envelope of words - substantives, verbs, prepositions, etc. - and their almost inevitably inaccurate meanings. If thus materializes an individual's chance of emerging as a social subject, this realization implies denial of the world of "thingness" for the world of significance. Lebrun indicates that acceptance into a language's world implies alienation, insofar as the decoupling from reality that this implies is usually forgotten in everyday practice.

It was Freud who first showed that elevation to the status of a subject implies a duality, a contradicting unity, the conscious and unconscious. For Lacan, if consciousness uses this unity to re-create reality and create the imaginary, the unconscious is structured as a language. Because a language has rules of its own, and implies obligations and makes demands, even as the unconscious shapes the subject's superficial and deep memory despite the subject itself, it plays the role of an Other as opposed to the Self. This structure of reflection has two characteristics that must be emphasized: on the one hand, it is incomplete, faulty, subject to indetermination; on the other, it is open-ended and ever-changing. Consequently, even as it enables the personal and social subject to emerge, it also conveys this incompleteness, this indetermination, this openness to change.

The last three paragraphs on the basics of psychoanalytical knowledge were needed to enable discussing the discourse of modern science, indelibly marked as it is by the metaphysics of presence that the blind objectivism of positive science but not Walras - obviously obscures and denies. Note, first, that the Other indicates the presence of otherness within the subject himself, which should not, however, strongly determine the subject, telling what it is and will become along the continuum of time.

If a subjectivity constitution process exists and if this process takes place by the setting of limits in relation to the Other, then this Other must be ever open to occupation by discourses stemming from society. In general terms, this is the usual dwelling place of the speeches of power, science, religion, etc. As Lebrun wrote: "the subjective and the social link together in the need to institute emptiness," that which fills in the gaps of each one's Other and is crucial to the formation of the individual mind; thus, the processes of "institutionalization and subject formation intertwine and move closely together" in the constitution of the ties that unite individuals to form society (Lebrun, 2008, p. 87).

Now, the Other is also ever the locus of struggles between for example, conformist and transformative enunciations of the individual and the social. Critical theories, psychoanalysis included, also strive to play a role in the formation of the Other that people keep within themselves without usually realizing that it is even there. But not to bring order to people's minds. Instead, to enable the subjects to recognize what comes from the Other and its dictums, to remain active in reflection, to allow themselves to doubt and question persons, institutions and themselves as needed, thereby thinking with a good degree of autonomy.

Nietzsche first proposed that the Modern age saw a victory of the scientific 
method over science itself (Lebrun, 2004, p. 51), a thesis that the critique of contemporary society must appropriate. On the one hand, the knowledge that scientism disseminates inexorably undermines the prevalence that the discourses of sovereignty and religion had in pre-Modern society. On the other hand, as a speech mode that aims to be exact, rigorous, even beyond dispute, science gains a level of authority that exceeds its own validity span, and thereby shapes social life as a whole. Obviously, this is not to challenge science as such, but to question its power to dictate right and wrong, to dictate behavior. Note, for example, that science now trespasses and constrains the realms of ethics and politics. According to Lebrun, it is not just that science may be taken as ideology, or has gained an ideological veneer, that is, a pretense of knowledge that somehow falsifies the understanding of reality. It is more than this.

It is about the following: today's ruling scientism does not just want to occupy an important pace in the Other of people in general, content in holding interpretative value to be embraced with caution and under democratic deliberation; it would go much further, as it aims for a validity of knowledge beyond challenge from all those that it affects, regardless of whether or not they master its codes. It would fill in the gap present in the Other like sovereignty and religion did in the current society's preModern past, that is, in medieval times. If the latter two discourses lost their primacy over Modern society, the discourse of science, and of positive science in particular, took their place with the main purpose of containing democracy in those areas sensitive to the power of the incumbent ruling class, that is, the bourgeoisie.

In addition, by standing as such, it enables a transfer of responsibility from experts, from the social actors that enunciate scientific knowledge, to a jurisdiction beyond their own, that is, to Science itself - an impersonal subject. The individual as subject therefore partly or fully abdicates its condition as subject of the enunciation, as the party who speaks and conveys what it believes should be proposed for the situation at hand, to become a transmission belt of the scientific knowledge conveyed, and thereby enjoying an authority it in fact lacks.

These excess takes place "because the scientific method [...] does in fact engender [...] a common scientism" that inflates the validity of the discourse of science itself (Lebrun, 2004, p. 55). The knowledge thus enunciated, contrary to Walras, must be regarded not just as science, but as technoscience. This is the case even when it presents itself as a theoretical tool capable of leading to moderate reformism or even a dictatorial and technocratic "socialism". This is perhaps why neoclassic theory is normally taught in several countries that still profess to be "Communist".

Science is ever a language construction, like all true or self-professed forms of knowledge about nature and society. By true, we mean good interpretations that can be supported by successful practical experiences. By the way, these can be regarded also as good interpretation of real events that are open to doubt, question and history. Not, however, that this conception of truth formally contradicts the design of modern science, as it pursues apodictic knowledge whose creditworthiness arises from the fact that it derives from exact methods. Contrary to this latter per- 
spective, science should never present itself as a strong discourse, one that cannot support democracy. And this lesson should be learned by economists.

The ideal science that Walras professes in the determination of prices becomes clearer once one realizes that his Platonism also includes Cartesianism: In order to know the reality - Descartes considered -, one should not start by experience, by the contact with the real world, but, on the contrary, it is necessary to get into conversation with itself, seeking clear and distinct ideas. Then, what is perceived is perceived very vividly and clearly is true (Descartes, 1983). Now, in this perspective, knowledge can only be regarded as true if it can be put into the demonstrative form of mathematical reasoning.

For Aristotle, this kind of knowledge was an episteme, that is, a knowledge that one might dictate to another with no need for discussion. The same author, however, also recognized knowledge as phronesis, that is, as practical understanding and/or prudent deliberation on moral and ethical matters. In the latter case, speech $^{3}$ must present itself with a rhetorical dimension ${ }^{4}$ - it does not dictate but try to convince other people. This tradition is not absent from Walras's understanding of science.

Unlike many of his successors, Walras criticized the view that excluded morality and politics from the realm of economic knowledge. As is well known, Walras was a social reformer who acted in favor of the nationalization of land in order to finance government. For him, the State should intervene in sectors dominated by monopolies. Furthermore, economic science could not be considered only as a natural science:

Such a point of view was particularly useful to [economists] in their controversy with the socialists [...]. [However,] convenient as this point of view is, it is mistaken. [...] Every proposal to reorganize production, every proposal to redistribute property was rejected a priori and practically without discussion. (Walras, 1954, p. 54).

According to this view, he wrote, all that is demanded on behalf of human interest and social justice may be dismissed as an artificial combination that must not be unduly introduced in the natural combination, which must prevail. He also wrote: "Man is a creature endowed with reason and freedom and possessed of a capacity for initiative and progress [in] the production and distribution of wealth" (ibid., p. 55). A creature, therefore, that can change the world according to its desire for a good life.

\footnotetext{
${ }^{3}$ In John L. Austin's (1911-1960) Speech Acts Theory: a locutionary act is the act of saying; an illocutionary act is the act of addressing another explicitly; a perlocutionary act is the act of attempting to bring about an effect in another by means of locution to influence their feelings and/or thoughts.

${ }^{4}$ In the contemporary political economy field, McCloskey stands out for her defense of the North American neopragmatist view. Even so, she still referred to political economy as Economics - which is rather contradictory (McCloskey, 1985).
} 
As shown, Walras did not exclude from scientific discourse the possibility pf prescribing structural social changes - to the contrary, he appears to regard them as rather necessary. ${ }^{5} \mathrm{He}$ truly believed that things should be subordinated to the democratic will of persons. But these are precisely the changes that most current neoclassic economists - not all of them for sure - strive hard to not allow because they rely on a knowledge that they deem superior or beyond question. Note, also, that contemporary ethics and politics can no longer be based on unbridled mastery over nature, which, ultimately, also means brutal mastery of men over men.

\section{REFERENCES}

Adorno, Theodor W. e Horkheimer, Max (1985) Dialética do esclarecimento - fragmentos filosóficos. Rio de Janeiro: Jorge Zahar Editores, 1985. [ADORNO, T. AND HORKHEIMER, M., Dialectics of Enlightenment - Philosophical Fragments. Stanford: Stanford University Press, 2002]

Carneiro Netto, Dionísio D. (1983) Apresentação: Walras. Os pensadores. São Paulo: Editora Abril, 1983. Descartes, René (1983 [1998]) “Discurso do Método”. In: Descartes, Os Pensadores. Editora Abril, 1983. [DESCARTES, R. - Discourse on Method. New York: Hackett Publishing Company, 1998].

Horkheimer, Max (1972 [1975]) Teoria tradicional e teoria crítica. Coleção Os pensadores. São Paulo: Editora Abril, 1975, p. 125-169. [HORKHEIMER, M., "Traditional and Critical Theory" in Critical Theory - Selected Essays. New York: Continuum Press, 1972]

Lebrun, Jean-Pierre (2004) Um mundo sem limite. Ensaio para uma clínica psicanalítica do social. Rio de Janeiro: Companhia de Freud, 2004.

Lebrun, Jean-Pierre (2008) A perversão comum - viver junto sem o outro. Rio de Janeiro: Companhia de Freud, 2008.

McCloskey, Deidre N. (1985) The rhetoric of Economics. Madison, Wisconsin: The University of Wisconsin Press, 1985.

Marx, Karl - O capital - Crítica da Economia Política, Livro Primeiro, tomo 1. São Paulo: Abril Cultural, 1983. [MARX, K. CAPITAL: A Critique of Political Economy, Volume I, Book One. London, Lawrence \& Wishart, 1867]

Smith, Adam (1983) A riqueza das nações - Investigação sobre sua natureza e suas causas. São Paulo: Abril Cultural, 1983. [SMITH, A., An Inquiry into the Nature and Causes of the Wealth of Nations. Edinburgh: Oliver D. Cooke, 1804]

Vattimo, Gianni - Adeus à verdade. (2009) Petrópolis: Editora Vozes, 2009. [VATTIMO, G., McCUAIG, W., \& VALGENTI, R. (2011). A Farewell to Truth. NEW YORK: Columbia University Press]

Walras, Léon (1983) Compêndio dos elementos de Economia Política pura. São Paulo: Abril Cultural, 1983. [Walras, L. (1954) Elements of Pure Economics. Translated by Jaffe, W., Allen and Unwin, London.]

\footnotetext{
${ }^{5}$ According to Carneiro, Walras was a social reformer who believed that the necessary transformations could only be brought about scientifically. He opposed "Say's reactionary rationalism and the wellmeaning emotionalism of the so-called 'utopian socialists' (in particular Proudhon, Fourier and SaintSimon)" (Carneiro Netto, 1983, p. x). It so happens that the best method for opposing undue interpretations lies with critical theory, not with metaphysical or traditional theory (Horkheimer, 1975).
} 